УAK 34(091)

ББК 67.3

DOI 10.22394/1682-2358-2019-1-93-98

B.D. Abdyraliev, postgraduate student of the Theory and History of State and Law Department, Kyrgyz National University named after J. Balasagyn

\section{THE INSTITUTION OF MARRIAGE UNDER THE KYRGYZ CUSTOMARY LAW (Based on the Epic of Manas)}

The institution of marriage in the Kyrgyz customary law system is studied on the basis of the cultural and legal source - the Manas epic. Theoretical understanding of the epic heritage of the Kyrgyz people in the light of law and statehood is given. The role of the epic is analyzed, which consists in the formation and strengthening of the moral and ethical foundations of society: the individual, the family, the state.

Key words and word-combinations: customary law, epic, family values, conditions of marriage, forms of marriage, legal customs of Kyrgyz people.
Б.А. АбдоралиеВ, аспирант кафедри теории и истории государства и праља Кьгргызского национального университета имени Ж. Баласагьна (email: gunara63@mail.ru)

\section{ИНСТИТУТ БРАКА ПО ОБЫЧНОМУ ПРАВУ КЫРГЫЗОВ \\ (по материалам эпоса «Манас»)}

Аннотация. Исследуется институт брака в системе обычного права кыргызов по материалам культурно-правового источника - эпоса «Манас». Эпическое наследие кыргызского народа осмысляется в соответствии с реалиями развития права и государственности. Анализируется роль эпоса, заключающаяся в формировании и укреплении морально-нравственных устоев общества: личности, семьи, государства.

Ключевые слова и словосочетания: обычное право, эпос, семейные ценности, условия заключения брака, формы брака, правовые обычаи кыргызов.

\section{$\mathrm{H}$} кционируют в кыргызском обшестве как неписаные правовые нормы, сохраняя регулятивную ценность в сфере сощиальных отношений, где особое место занимают вопросы семьи и брака. Примером может служить устный источник - эпос «Манас», в котором сосредоточен комплекс соџиальнокультурных, политических, юридических и Аругих свеАений о жизни и быте кочевого 
традищионного общества. Значительное место в эпосе отведено описаниям эпизодов, посвященных общеполитическим вопросам - военным походам, заключению мира, избранию хана и созыву народного собрания (курултая); затронуты вопросы хозяйственного значения, в частности брачно-семейных отношений в кочевом обществе, где имелись правовые институты сватовства и заключения брака, имущественных отношений и калыма, материального содержания нетрудоспособных членов семьи (вдов и детей, престарелых чиенов семьи, сирот, малообеспеченных чиенов рода). Освященные многовековыми традиџиями семейно-брачные нормы отражают особенности патриархально-родовых отношений с сицьно выраженными явлениями родственной солидарности и сплоченности, связанными с историческим развитием кыргызского народа.

Принятие Закона Кыргызской Республики от 28 июня 2011 г. № 59 «Об эпосе ”Манас"» послужияо импульсом к исследованию в целях попумяризаџии, воспитания и формирования морацьно-нравственных идеалов общества.

Многие правовые обычаи кыргызов - калым, сватовство, умыкание невесты, мевират и прочие - параммельно существовами и в правовых системах Аругих кочевых обществ Центрацьной Азии (казахов, хакасов, туркмен, каракалпаков, тувинцев). Выдающийся русский реформатор М.М. Сперанский, будучи генерал-губернатором Сибирской губернии, в разработанном им Уставе об управлении инородџев отметил особенность и стабильность обычного права у алтайцев, тувинцев, хакасов, якутов и Аругих народностей и закрепил, что «все кочующие и бродячие инородџы управляются по их собственным степным законам и обычаям» [1]. Впервые в России всем народам предоставцялось право обустройства жизни по собственным законам, тем самым юридически закреплялись нормы обычного степного права.

Брачно-семейные отношения кыргызов в досоветский период регулировались нормами обычного права (адата); в сику кочевого образа жкизни, требовавшего мирного сосуществования родов, единства семьи и прочности родственных взаимоотношений, сохранялись большие патриархальные семьи. В традиционном кыргызском обшестве важнейшими семейными ценностями считались уважение и почитание старших, главенство мужчины в семье, родственная взаимопомощь, продолжение рода, обеспечение родового единства, непременная забота о пожилых, слабых, вдовах и детях.

Рассматривая условия заключения брака по обычному праву, С.М. Абрамзон отмечает, что браки у кырғызов запрещались межАу родственниками по

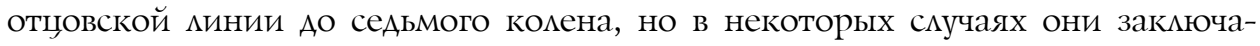
$\Lambda и с ь$ в третьем - четвертом колене [2, с. 232]. Наиболее распространенной формой брака у кыргызов являлся брак «по сговору». Такой брак заключался поэтапно, с соблюдением определенных условий и обрядов (сватовство, надевание серег, свадебное преподношение, калым, заключение брака, празднество), где особое место принадлежало институту калыма. Кыргызы с уважением относицись к чести и достоинству девушки, и калым служиц доказательством имущественной состоятельности стороны жениха и его родственников, зна-

\section{Bulletin of the Volga Region Institute of Administration • 2019. Vol. 19. № 1}


ком почтения к невесте и ее родственникам, важной компенсацией, возмещающей расходы на сбор приданого [3, с. 149] .

Сватовство и женитьба мюбого кыргыза, особенно знатного человека, требовало знания всех тонкостей и правиц, которых следовало придержкиваться обеим сторонам. По сути заключение брака осуществлялось родителями жениха и невесты. Часто будущая невеста не имела представления о своем женихе. Всякое сопротивление вступцению в брак не имело значения дия обеих сторон и рассматривалось как нарушение норм адата (обычного права).

В эпосе «Манас» отец героя Ажакып, оценив по достоинству качества Аочери таджикского правителя Атемир-хана - Санирабийги, сватает девушку и, согласившись с небывалыми размерами установленного ее отцом калыма, возвращается обратно. После того как народом собран скот мля уплаты калыма, Манас в сопровождении Авенадџати тысяч Ажкигтов и сорокатысячного войска отправмяется с отџом в страну таджиков получить согласие невесты и заключить брак.

Норма обычного права обязывала оказывать помощь сопиеменнику в случае уплаты им не толыко Аолга или штрафов, но и калыма. Калым - это своего рода имущественная слелка, выкуп за невесту. Калымной формой брака является сговор о браке малолетних детей (брак до рождения, колыбельный брак, перекрестный брак). При обменном браке кайчы-куда (перекрестные сваты) обменивались дочерьми. В эпосе нет сведений о возрасте, с которого можкно заключить брак, но родители могли сосватать и в детстве, заключив договор сватовства устно, при свидетелях. В эпосе описывается эпизод обручения детей до их рождения, где герой заключает соглашение с афганским владетелем Акун-ханом о будущем браке ожидаемых детей. У первого рождается сын Семетей, у второго - Аочь Айчурок, которые становятся женихом и невестой, а затем - мужем и женой.

В рукописи об обычаях кыргызов Токмакского уезда 1893 г сообщается: «по обычаю в уплате калыма должны помогать жениху его родственники и если бы он быц настолько состоятелен, что сам мог бы уплатить калым, он все-таки просит помощи, потому что он ранее сам помогал родным и знает, что будет помогать после, а потому случаем своей женитьбы пользуется, чтобы вернуть то, что сам израсходовац на помощь» [4]. Казахский ученый Ч. Вациханов подчеркивает: «Размер калыма зависец от соџиального положения вступающих в брак, от материального положения их родителей, а также от достоинства невесты. Камым у богачей безграничен: 100 мошадей, 20 рабов, 10 беркутов и 10 ружей. Простой же народ продает дочерей по умеренной цене: 20 или 30 голов скота» [5, с. 371]. В тувинском кочевом обшестве размер и величина калыма зависели от социального и имущественного статуса сторон, при этом выкуп у тувинцев являлся своеобразным Ааром, который символизировал признание заслуг родителей и рода в воспитании невесты [6] .

Недостающая сумма после уплаты самим должником раскладывалась межАу чиенами общины. Это свидетельствует о том, что формы ответственности, которые применяются действующим гражданским законодательством как возмещение реального вреда и уплата штрафа, применялись и в кочевой общине. 
Кыргызскому обществу известны формы бескалымных браков, отличающихся мотивами и условиями заключения (брак с отработкой, перекрестный брак, взятие наложниц). Бедняк, не располагавший средствами дмя уплаты калыма и не имевший близких родственников, на помощь которых он мог бы рассчитывать, вынужден был прибегать к такой форме бескалымного брака, как отработка за жену. Такого мужчину брал к себе в дом и делал зятем человек, не имеющий собственного сына и нужАающийся в рабочей симе Амя своего хозяйства. Прожив несколько мет и «отработав» жену, бедняк получал право забрать ее.

В условиях военной демократии и кочевого образа жизни у кыргызов существовала полигиния, или многоженство, которой пользовались главным образом зажиточные слои общества, поскольку в материальном плане муж обязан быц одинаково содержать всех жен [7, с. 276]. Мотивами полигинии являлись определенные обстоятельства: гибель значительного количества мужчин в результате междоусобных войн, отсутствие сыновей как продолжателей рода, бездетность. При такой форме брака женщины и их дети не оставались без кормильца, а большинство кыргызских женщин получали возможность реализовать естественное право стать одновременно женой и матерью.

Примером института сватовства и заключения брака служит следующий эпизод эпоса: герой-богатырь Манас, имея двух навязанных ему обстоятельствами жен-наложниц - Карабёрк и Акылай, знал, что отеџ не очень-то мюбит расставаться со своим добром и, по сути, не понес никаких расходов на его женитьбу, поскольку обе жены достались Манасу как военные трофеи. Он решил пристыдить отца и заставить его выполнить освященный традициями отцовский Аолг по поискам невесты, сватовству, проведению свадьбы и т.А. [8, с. 137]. Законная жена Манаса - Каныкей, следуя соџиальному статусу мужа, получияа статус ханши - цариџы кыргызов на Енисее.

Только через мужа женщина в кочевом обшестве приобретала соџиально значимый статус и получала признание в обществе. По той же причине в традиционном обществе кыргызов редко допускались разводы. Специфические, суровые условия жизни кочевников и гибель значительного количества мужчин в военных столкновениях предопределили усложнение форм законного брака такими аспектами, как мевират и сорорат. Об этом упоминает казахский ученый С. Узбекулы: «В недавнем прошиом у кочевых кыргызов повсеместно были распространены формы брака поА названием цевират и сорорат, у казахов - институт аменгерства» [9, с. 67]. Схожие обычаи отмечает Т.Н. Медведева у хакасов: «При мевиратном браке, когда вдова оставалась в доме мужа и выходила замуж за одного из его братьев, собственность семьи переходияа к Аругим чменам семьи умершего мужа, в большей степени к ее новому мужу, который наделямся и правами и обязанностями опекуна» $[10$, с. 11$]$.

Согласно этому обычаю, широко распространенному у народов, находящихся на ранних ступенях общественного развития, на вдове старшего брата должен жениться младший брат (или кто-нибудь из ближайших родичей покойного). Аевират явмяется пережитком группового брака, комлективного 
права рода на жену родича. Этот обычай до недавнего времени существовал у тюркских народов. На нем построен сюжет казахской поэмы «Кыз Жибек». Сорорат - менее распространенное явление. Право сорората предполагает женитьбу мужчины-вдовца на непросватанной сестре жены, при этом калым платится как при первом браке. Следует признать, что эти браки заключались только с согласия женщины.

Социальная функция мевирата заключалась в том, что после смерти мужа или отца семья сохранялась дия целостности рода, продомжая оставаться объектом опеки со стороны родственников покойного. Во-первых, учитывались интересы детей как продолжателей рода; во-вторых, чтобы не допустить потери части собственности - приданого и калыма (Авижимого и недвижимого имущества), сноху старались выдать замуж, не позволяя ей покинуть род. Право мевирата распространялось на всех вдов [11, с. 179]. В эпосе «Манас» описана женитьба хана Ажакыпа на вдове его старшего брата Чыйыра (Чийырды), отражающая старинный обычай мевирата.

По обычному праву кыргызов, описанному в эпосе «Манас, чаще всего заключалась эндогамная форма брака; встречались и межродовые (династийные) браки дяя поддержания добрых отношений с соседями. Аля усияения кровнородственных отношений заключались кузенные, ортокузенные и кросскузенные браки.

Согласно требованиям минората в обычном праве кыргызов, младший сын, женившись, не имел морального права требовать отделения в самостоятельное хозяйство: на нем межала обязанность содержкать стариков - родителей. По правилам универсального правопреемства он наследовал все имущество отца: юрту, дом, домашнюю утварь, хозяйство отца, его земельные наделы, имущественные права. Вместе с имуществом наследовались обязательства и долги. Основной наследуемой обязанностью было содержание жены отџа, которая, как правило, приходикась ему матерью. В обычном праве кыргызов и казахов брачный союз считался священным, часто не зависел от воли обеих сторон и браки не расторгались, поскольку мужчина, приняв в свой род женщину, брал на себя обязательство Ао конџа жизни проявмять заботу о ней и ее детях.

Мотивы эпоса «Манас» свидетельствуют о том, что родство у кыргызов велось по мужской минии и имело законную силу в глазах общественного мнения. ОАнако в повседневной жизни родству по кинии матери придавалось не меньшее значение, а родственники со стороны матери считались наиболее близкими, так как при сушествовавшей системе брачных отношений группа родственников со стороны матери нередко почти полностью совпадала с группой родственников со стороны жены [12, с. 162].

С современной точки зрения демократичность норм обычного права кыргызов выражалась в ясном установлении прав и обязанностей всех чкенов семьи, высоком, по сравнению с Аругими цивилизациями, положении женщин и защите интересов не только семьи, но и всего рода. В условиях роста самосознания и идентификации наций можно составить наиболее полное представление о морамьно-этических ценностях и соџиально-правовых от- 
ношениях кыргызского народа, отраженных в устном культурно-правовом памятнике - эпосе «Манас».

Сегодня в Кыргызстане на смену прежней приходит новая система семейных ценностей: утрата традиционных семейных уз и связей, появление ранее не сушествовавших видов семейных отношений - однополый брак, гражАанский брак, внебрачные дети, массовые разводы, не свойственные нормам традиционной правовой культуры кыргызского общества [13, с. 10]. Понятия уважения к мюдям и мичности, семейно-родственных отношений, равенства, сложившиеся в системе обычного права, закреплены в статьях Конституции Кыргызской Респубцики, что Аоказывает актуальность и жизнеспособность традиций и обычаев, передаваемых героическим эпосом «Манас». Таким образом, институт брака как один из факторов сохранения и саморегулирования общества остается объектом исследования правовой науки.

\section{Библиографический список}

1. Кряжков B.A. Статус малочисленных народов России. Правовые акты. М.,1999. 1990 .

2. Абрамзон С.М. Киргизы и их этногенетические и историко-культурные связи. Фрунзе,

3. Сооронкулова К.С. Обычное право и современная правовая система Кыргызской Республики. Бишкек, 2009.

4. ЦГИА КазССР. Ф. 64. Оп. 1. Д. 5089. Разд. V. Семья. §7.

5. Валиханов Ч.Ч. Собрание сочинений: в 5 т. Алма-Ата, 1961. Т. 1.

6. Дамдынчап B.M. Роль обычного права в развитии тувинского общества: автореф. дис. ... канд. ист. наук. URL: http://cheloveknauka.com/rol-obychnogo-prava-v-razvitii-tuvinskogo-obschestva

7. Мукамбаева Г.А. Манас и право. Бишкек, 2003.

8. Байджиев М. Сказание о Манасе: поэтическое переложение первой части трилогии эпоса «Манас». Бишкек, 2010.

9. Узбекулы С. Право кочевой цивилизации казахов. Алматы, 2002.

10. Медведева T.Н. Обычное семейное право: автореф. дис. ... канд. ист. наук. Томск, 2004. 2004.

11. Борубашов Б.И., Галиева З.И. История государства и права Кыргызстана. Бишкек,

12. Борубашов Б.И. Государственно-правовое регулирование общественных отношений кыргызов в составе Российского государства 1855-1917 гг.: историко-правовое исследование: дис. ... д-ра юрид. наук. Бишкек, 2009.

13. Айдарбекова Г.Б. Проблемы формирования национальной правовой культуры в Кыргызстане // Вестник Уральского института экономики, управления и права. 2010. № 2. 